\title{
Tolerance to waterlogging in Parkia gigantocarpa Ducke saplings
}

\section{Waldemar VIANA DE ANDRADE JÚNIOR ${ }^{1}$ Benedito GoMES DOS SANTOS FILHO ${ }^{2}$ Cândido Ferreira de Oliveira Neto ${ }^{1}$ Eniel David CRUZ ${ }^{3}$ \\ Ricardo SHIGUERU OKUMURA 2,4 Vitor RESENDE DO NASCIMENTO ${ }^{1}$ Jéssica TAYNARA dA SILVA MARTINS ${ }^{2,5}$ Liliane CORRÊA MACHADO 2,5 Diana Jhulia Palheta de Sousa ${ }^{2}$ Jéssica Suellen SIIVA TEIXEIRA ${ }^{2}$ \\ ${ }^{1}$ Federal Rural University of the Amazon Forest Sciences Department Laboratory of Biodiversity Studies of Upper Plants 66.077-830 Campus Belém, Pará Brazil}

${ }^{2}$ Federal Rural University of the Amazon Institute of Agronomists Sciences 66.077-830 Campus Belém, Pará Brazil

${ }^{3}$ Brazilian Agricultural Research Corporation (Embrapa) 66017-970 Belém, Pará Brazil

${ }^{4}$ University of the Amazon (UFRA) Agronomy student at Federal Rural Belém, Pará

Brazil

${ }^{5}$ Federal University of Santa Maria Fitotecnia Department 97105-900 Campus Sede Santa Maria, Rio Grande do Sul Brazil

\section{Auteur correspondant /}

\section{Corresponding author:}

Waldemar Viana de Andrade Júnior waldemarandrade97@gmail.com

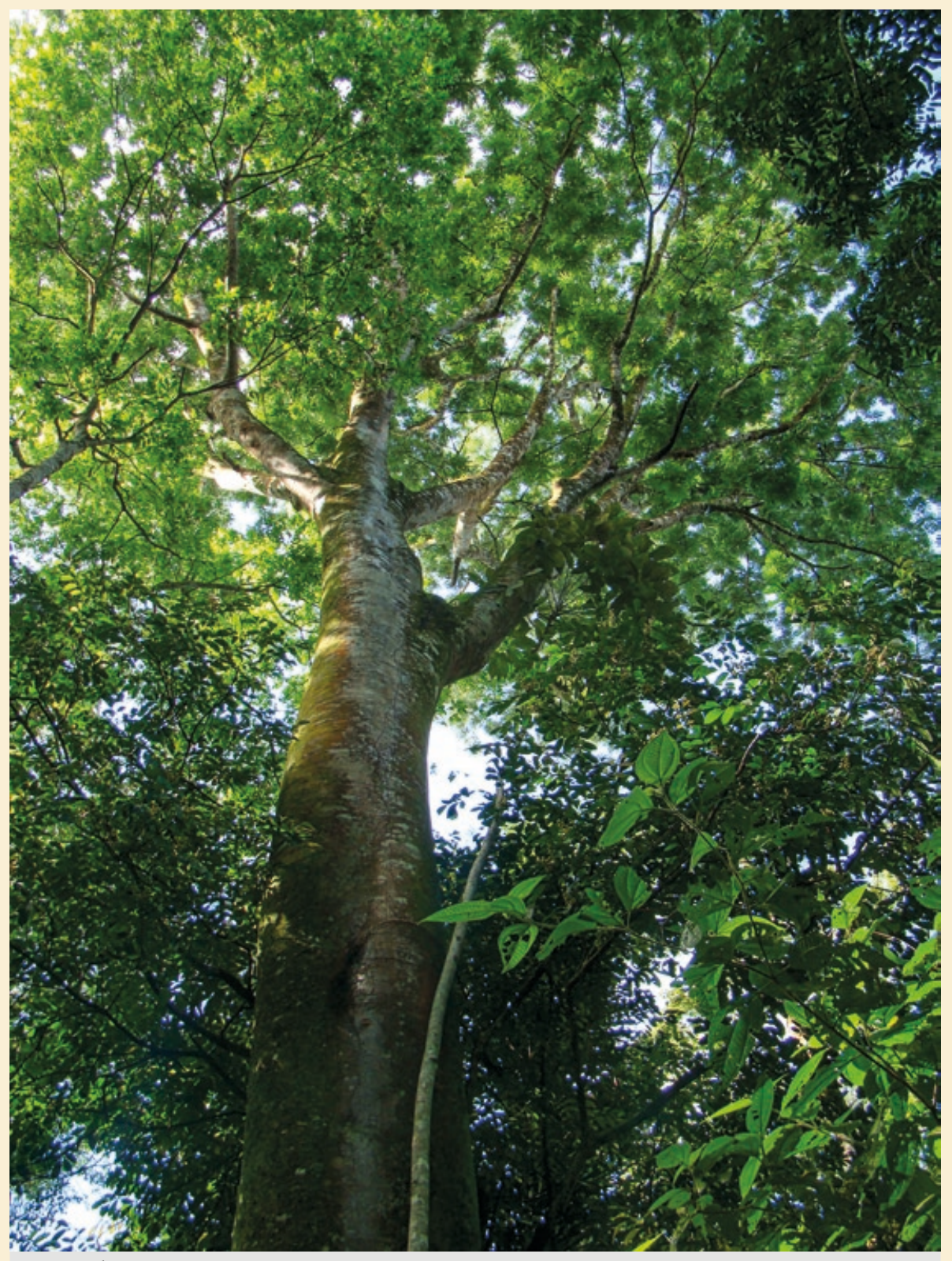

Photo 1.

Parkia gigantocarpa.

Photo E. D. Cruz.

Doi : 10.19182/bft2019.341.a31759 - Droit d'auteur (c) 2019, Bois et Forêts des Tropiques - (c) Cirad - Date de soumission : 21 septembre 2018 ; date d'acceptation : 26 février 2019 ; date de publication : $1^{\text {er }}$ juillet 2019.

\section{Cirad ata}

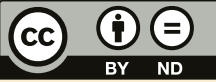

Licence Creative Commons :

Attribution - Pas de Modification 4.0 International. Attribution-NoDerivatives 4.0 International (CC BY-ND 4.0)
Citer l'article / To cite the article

Viana de Andrade Júnior W., Gomes dos Santos Filho B., Ferreira de Oliveira Neto C., Cruz E. D., Okumura R. S., Resende do Nascimento V., Taynara da Silva Martins J., Corrêa Machado L., Palheta de Sousa D. J., Silva Teixeira J. S., 2019. Tolerance to waterlogging in Parkia gigantocarpa Ducke saplings. Bois et Forêts des Tropiques, 341: 79-86. Doi: https://doi.org/10.19182/ bft2019.341.a31759 


\section{RÉSUMÉ}

\section{Tolérance à l'engorgement d'eau chez les arbrisseaux de Parkia gigantocarpa Ducke}

Cette étude se propose d'évaluer les réponses biochimiques des arbrisseaux de Parkia gigantocarpa devant l'engorgement d'eau. L'engorgement est appliqué en inondant les arbrisseaux dans des pots de $14 \mathrm{~kg}$ jusqu'à approximativement $5 \mathrm{~cm}$ au-dessus de la surface du sol. Le plan expérimental a été façonné aléatoirement et comprenait deux types d'application de l'eau (contrôle et engorgement) sur cinq périodes d'évaluation (après 0 , $4,8,12$ et 16 jours d'engorgement), avec cinq réplications par traitement. Amidon, saccharose, hydrates de carbone solubles totaux et protéines solubles totales ont été mesurés. Les arbrisseaux soumis à engorgement ont montré des réductions significatives des concentrations d'amidon $(62,50 \%)$ et de protéines solubles totales $(40,98 \%)$, en particulier dans les feuilles. L'engorgement a réduit la concentration de saccharose dans les feuilles (44,38\%), tandis que cette concentration a augmenté dans les racines $(76,78 \%)$. La concentration d'hydrates de carbone solubles a augmenté de $106,9 \%$ dans les racines des plantes exposées à l'engorgement. Cette étude a démontré la sensibilité des arbrisseaux de Parkia gigantocarpa à l'engorgement.

Mots-clés : amidon, saccharose, hydrates de carbone solubles totaux, protéines solubles totales, Brésil.

\section{ABSTRACT}

\author{
Tolerance to waterlogging in Parkia \\ gigantocarpa Ducke saplings
}

This study aimed to assess the biochemical responses of Parkia gigantocarpa saplings to waterlogging. Waterlogging was imposed by flooding the saplings in $14 \mathrm{~kg}$ pots to approximately $5 \mathrm{~cm}$ above the soil surface. The experimental design was completely randomized and involved two water conditions (control and waterlogging) over five assessment periods (after 0, 4, 8, 12 and 16 days of waterlogging), with five replications per treatment. Starch, sucrose, total soluble carbohydrates and total soluble proteins were measured. The saplings exposed to waterlogging showed significant reductions in starch concentrations $(62.50 \%)$ and total soluble proteins (40.98\%), especially in the leaves. Waterlogging reduced the concentration of sucrose in leaves (44.38\%) and increased it in the roots $(76.78 \%)$. The total soluble carbohydrate concentration increased by $106.9 \%$ in the roots of plants exposed to waterlogging. This study showed the susceptibility of Parkia gigantocarpa saplings to waterlogging.

Keywords: starch, sucrose, total soluble carbohydrates, total soluble proteins, Brazil.

\section{RESUMEN}

\author{
Tolerancia al encharcamiento en los \\ arbolitos de Parkia gigantocarpa Ducke
}

Este estudio tiene como objetivo evaluar las respuestas bioquímicas de los arbolitos de Parkia gigantocarpa al encharcamiento. El encharcamiento se consiguió inundando los arbolitos en recipientes de $14 \mathrm{~kg}$ hasta aproximadamente $5 \mathrm{~cm}$ por encima de la superficie del suelo. El diseño experimental fue completamente aleatorizado y tuvo en cuenta dos condiciones para el agua (control y encharcamiento) durante cinco períodos de evaluación (después de 0 , 4, 8, 12 y 16 días de encharcamiento), con cinco réplicas por tratamiento. Se midieron: almidón, sacarosa, hidratos de carbono solubles totales y proteínas solubles totales. Los arbolitos sometidos a encharcamiento mostraron reducciones significativas de las concentraciones de almidón (62,50\%) y de proteínas solubles totales $(40,98 \%)$, especialmente en las hojas. El encharcamiento redujo la concentración de sacarosa en las hojas $(44,38 \%)$ y la incrementó en las raíces $(76,78 \%)$. La concentración total de hidratos de carbono solubles aumentó en un $106,9 \%$ en las raíces de las plantas sometidas a encharcamiento. Este estudio ha mostrado la sensibilidad de los arbolitos de Parkia gigantocarpa ante el encharcamiento.

Palabras clave: almidón, sacarosa, hidratos de carbono solubles totales, proteínas solubles totales, Brasil. 


\section{Introduction ${ }^{1}$}

Waterlogging is an abiotic factor, common in many regions of the world, promoted by natural or anthropogenic causes, such as increase in the water level of rivers, poor irrigation management, unfavorable topography, poor soil drainage (Patel et al., 2014), removal of vegetation and construction of dams and roads. In addition, as a result of global climate change, there are forecasts of extreme weather events such as heavy rains, which may affect the frequency, duration and intensity of waterlogging in certain regions (IPCC, 2012), thus representing a problem to forestry, agriculture, and permanent preservation areas.

Waterlogging fills the soil porous spaces, causing hypoxia or anoxia, changing the aerobic metabolic pathway into the anaerobic one, thus reducing energy (adenosine triphosphate, ATP) to the root system. Decreases root development, resulting in less absorption and transport of water and nutrients to the shoot, thereby negatively influencing the stomatal conductance, transpiration and photosynthesis of many plants (Mollard et al., 2010). Due to the low efficiency of these processes, the energy and carbon metabolism of trees are usually strongly affected in the roots and shoots (Kreuzwieser et al., 2009).

The increase of carbohydrate in the leaves, for example, is due to starch accumulation (Liu et al., 2011) or decreased translocation, which is severely reduced by numerous species of plants that are non-tolerant to waterlogging environments (Bertolde et al., 2012).

Accumulation of sucrose (Merchant et al., 2010) and soluble carbohydrates (Bertolde et al., 2012) fosters osmotic adjustment, i.e., accumulation of these compounds, especially in the cytoplasm, thus reducing the osmotic potential of leaf tissue cells, and, consequently their water potential (Jaleel et al., 2007). As a result, a water potential gradient is found between air-root-shoot, allowing absorption and transport of soil water to the shoot, thereby contributing to the maintenance of cell turgor.

Parkia gigantocarpa known in Brazil as fava-atanã is a neotropical tree that occurs naturally in upland and lowland floodplains. In recent years, it has aroused the interest of researchers, especially related to seedling production (Oliveira et al., 2012) and commercial timber activities in the Amazon region (Reis et al., 2014). Because of its rapid growth, uniformity, low mortality rate and economic and ecological potential, it is seen as promising species for recovery of altered or degraded areas, especially those aimed at permanent preservation (Carvalho, 2010). Moreover, they can also be used in forestry systems (Andrade Júnior et al., 2016).

Despite the economic, ecological and environmental importance of $P$. gigantocarpa, few studies (Andrade Júnior et al., 2016) have been conducted to clarify its biochemical behavior in waterlogging conditions, especially in

1 Abbreviations: $\Psi$ x: foliar xylem water potential; TSC: total soluble carbohydrates; TSP: total soluble proteins; Stleaf: Starch in leaf; Stroot: Starch in root; Sacleaf: Sucrose concentration in leaf; Sacroot: Sucrose concentration in root; ATP: Adenosine

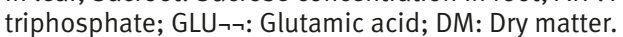

the initial phase of development. The understanding of the behavior of tree species with economic and environmental potential in the early stages of vegetative development under flood conditions may support the reforestation of degraded areas. Thus, the aim of the study was to evaluate the biochemical responses of young $P$. gigantocarpa plants exposed to waterlogging conditions.

\section{Materials and methods}

\section{Study location}

The experiment was conducted in a greenhouse at the Instituto de Ciências Agrárias (Institute of Agricultural Sciences, ICA) of the Universidade Federal Rural da Amazônia (Federal Rural University of the Amazon, UFRA) in the city of Belém, State of Pará, Brazil ( $0^{\circ} 28^{\prime} 03^{\prime \prime}$ S, 48²9'18”W) during 120 days.

\section{Plant materials}

P. gigantocarpa Ducke seeds were collected from Rio Capim farm (0341'07"S and 48 $\left.38^{\circ} 04^{\prime \prime} W\right)$. Seeds were scarified in the lateral region and adjacent to the hilum, and were immediately sown in $5 \mathrm{~L}$ plastic trays containing sterile sand. After emergence, the seedlings were transplanted to black opaque polythene bags measuring $25 \mathrm{~cm} \times 15 \mathrm{~cm}$ in height and diameter, respectively, with perforations in all sides, containing the substrate Plantmax ${ }^{\circledR}$ (composed of composted pine bark, peat, vegetal charcoal, and vermiculite). The seedlings were grown for 60 days. After this period, plants were evaluated for height, stem diameter, number of leaves and number of leaflets, and transferred to $14 \mathrm{~kg}$ plastic pots, containing the same substrate used in transplanting. The pots with the young plants were placed in a greenhouse for acclimation, during 45 days.

\section{Experimental design}

The experimental design used was factorial randomized with two water conditions (control and waterlogging) combined with five evaluation periods $(0,4,8,12$ and 16 days of waterlogging conditions). The experiment was assembled with five replications in a total of 50 experimental units, with one plant per unit.

\section{Waterlogging treatments}

After the acclimation period, at approximately 4 months of vegetative growth, all young $P$. gigantocarpa plants were subjected to water treatments. Control plants were irrigated daily with $2.5 \mathrm{~L}$ of water to replace water lost by evaporation; this was done individually for each pot, while considering the daily weighting set (pot + plant + soil). In the treatment exposed to waterlogging conditions, the plants were placed in pots without drains to avoid water drainage, with water level maintained at $5 \mathrm{~cm}$ above the soil surface. Control and waterlogging plants remained for 16 days under these conditions. 


\section{Starch content}

For determination of starch content, $50 \mathrm{mg}$ of milled material (leaf and root) were incubated with $5 \mathrm{~mL}$ ethanol at $80^{\circ} \mathrm{C}$ for $30 \mathrm{~min}$, centrifuged at 2,000 rpm for $10 \mathrm{mn}$ at $25^{\circ} \mathrm{C}$, and the supernatant was removed. In addition, a second extraction was carried out with the same milled material incubated with $5 \mathrm{~mL}$ of $30 \% \mathrm{HClO}_{4}$ at $25^{\circ} \mathrm{C}$ for $30 \mathrm{~min}$ and centrifuged in the conditions described previously. The supernatants of the two extractions were mixed. The quantifications of the total soluble carbohydrates and starch were carried out at $490 \mathrm{~nm}$ using the method of Dubois et al. (1956), using glucose (Sigma Chemicals) as a standard.

\section{Sucrose content}

Determination of sucrose was carried out with $50 \mathrm{mg}$ of powder (leaf dry matter), which was incubated with $1.5 \mathrm{~mL}$ of MCW solution (methanol, chloroform and water), in a 12:5:3 ratio (v:v-1) at $20^{\circ} \mathrm{C}$ by $30 \mathrm{mn}$ and under agitation. Subsequently, the homogenate was centrifuged at $10,000 \mathrm{rpm}$ by $10 \mathrm{mn}$ at $20^{\circ} \mathrm{C}$ and the supernatant was removed. Sucrose quantification was carried out at $620 \mathrm{~nm}$ according to Van Handel (1968), and sucrose (Sigma chemicals) was used as a standard.

\section{Determination of total soluble carbohydrates (TSC)}

Total soluble carbohydrates were determined with $50 \mathrm{mg}$ of leaf dry matter, which was incubated with $5 \mathrm{~mL}$ of ultra pure water at $100^{\circ} \mathrm{C}$ by $30 \mathrm{mn}$; subsequently, the homogenate was centrifuged at 2,000 rpm for $5 \mathrm{mn}$ at $20^{\circ} \mathrm{C}$ and the supernatant was removed. Quantification of total soluble carbohydrates was carried out at $490 \mathrm{~nm}$ according to the method of Dubois et al. (1956), and glucose (Sigma Chemicals) was used as a standard.

\section{Concentrations of total soluble proteins (TSP)}

Determination of total soluble proteins was carried out with $100 \mathrm{mg}$ of powder, incubated with $5 \mathrm{~mL}$ of extraction buffer. This was homogenized and kept in agitation for $2 \mathrm{~h}$, and centrifuged at 2,000 rpm for $10 \mathrm{mn}$ at $20^{\circ} \mathrm{C}$. Quantification of total soluble proteins was carried out at $595 \mathrm{~nm}$ in accordance with Bradford (1976) with albumin bovine (Sigma Chemicals) as a standard.

\section{Data analysis}

The data were subjected to variance analysis and significant differences between means were determined using the F-test at the $5 \%$ error probability level (Steel et al., 2006). Standard deviations were calculated for each treatment at all evaluation points. A correlation analysis was performed using Pearson's parametric method, and the statistical analyses were performed using the SAS software (SAS, 2007).

\section{Results}

\section{Waterlogging effects on starch concentration}

Starch concentrations in the leaf tissue were significant lower in plants exposed to waterlogging (figure 1a). There was interaction between the factors $(P<0.001)$, statistical differences between treatments $(P<0.001)$ and evaluation periods ( $P<0.001$ ) (figure 1$)$. At 16 days of the experiment, starch concentrations were $0.24 \mathrm{mmol} / \mathrm{g}$ GLU residue in control plants and $0.09 \mathrm{mmol} / \mathrm{g} \mathrm{GLU}$ residue in waterlogged plants, with a reduction of $62.5 \%$ in plants exposed to waterlogging (figure 1a). Starch concentrations in root also showed significant interaction between the factors $(P<0.001)$, statistical differences between treatments $(P<0.001)$ and evaluation periods $(P<0.001)$ (figure 1$)$.

At 16 days of the experiment, concentrations of starch reduced from $0.09 \mathrm{mmol} / \mathrm{g} \mathrm{GLU}$ (control) to $0.04 \mathrm{mmol} / \mathrm{g}$ GLU (waterlogged) residue, a decrease of $55.55 \%$ in plants exposed to waterlogging (figure $1 \mathrm{~b}$ ).

\section{Sucrose concentration in $P$. gigantocarpa}

In relation to sucrose concentration, there was interaction between the factors $(P<0.001)$, statistical differences between treatments $(P<0.001)$ and periods of evaluation $(P<0.001)$ (figure 2ab). The concentrations of sucrose in leaves at 16 days were, 27.66 and $15.38 \mathrm{mg}$ in the control and waterlogged plants, respectively, a decrease of

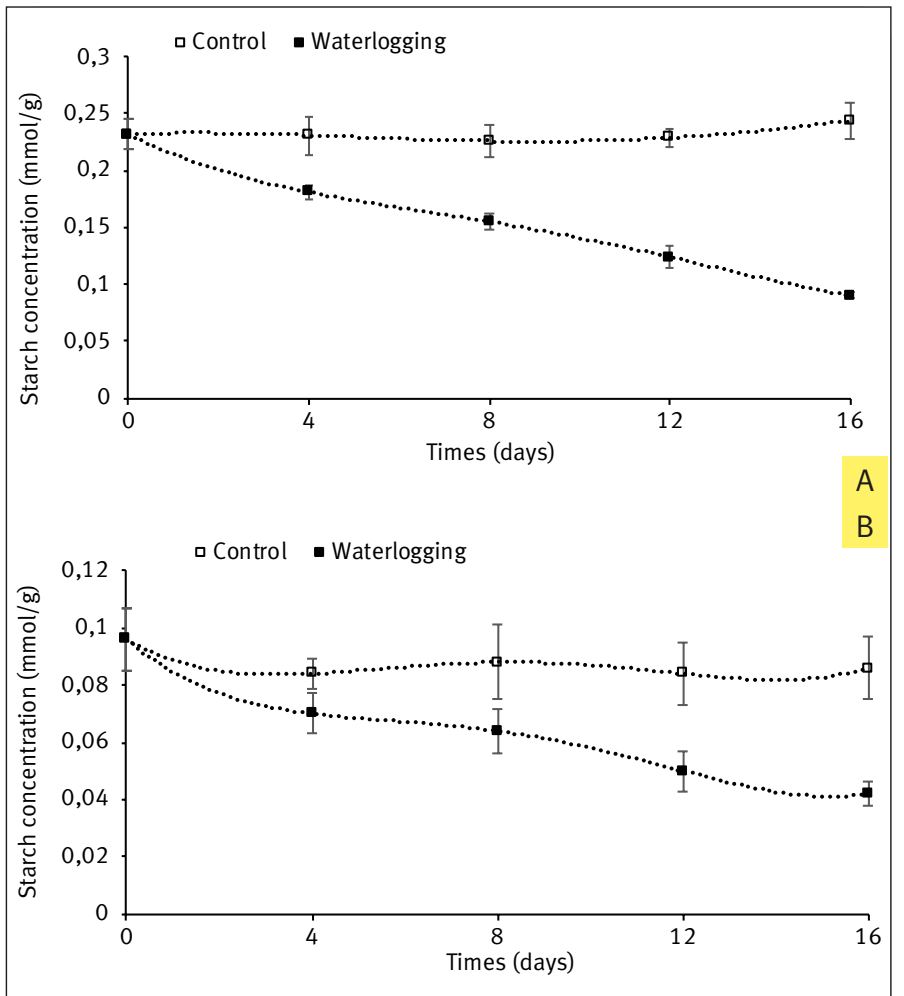

Figure 1.

Starch concentration in the root (A) and the leaf (B) in young Parkia gigantocarpa plants exposed to waterlogging conditions. Squares represent the mean values of five replicates, and error bars represent the mean standard errors. 


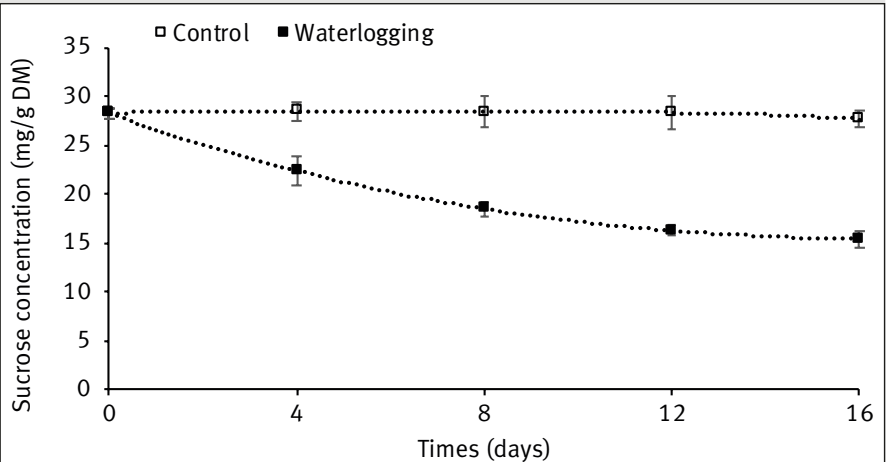

A

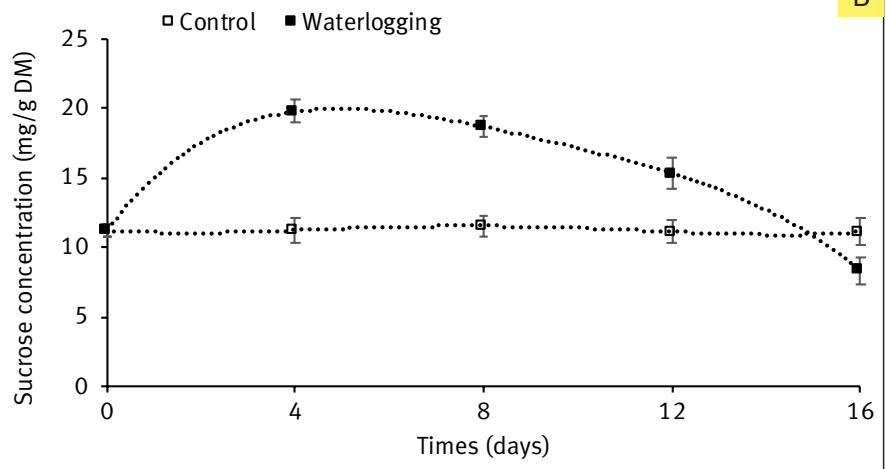

Figure 2.

Sucrose concentration in the root (A) and the leaf (B) in young Parkia gigantocarpa plants exposed to waterlogging conditions. Squares represent the mean values of five replicates, and error bars represent the mean standard errors.
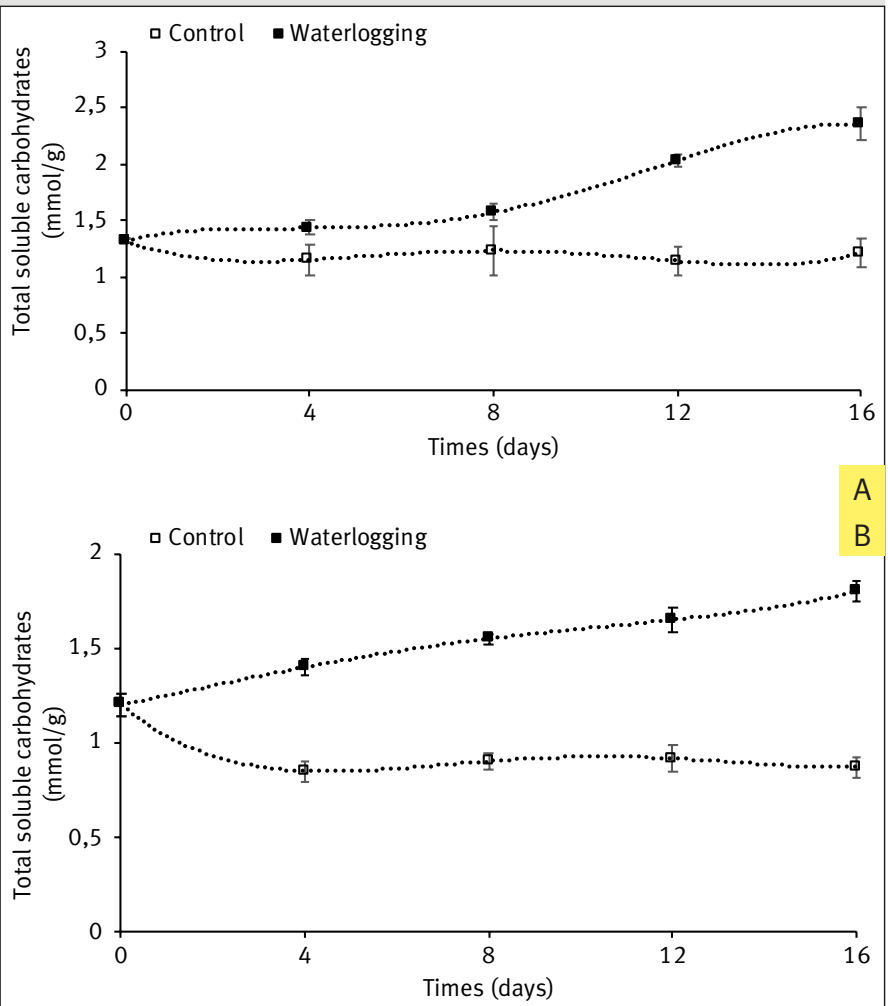

Figure 3.

Total soluble carbohydrates concentration in the root (A) and the leaf (B) in young Parkia gigantocarpa plants exposed to waterlogging conditions. Squares represent the mean values of five replicates, and error bars represent the mean standard errors.
$44.38 \%$ in plants exposed to waterlogging (figure $2 \mathrm{a}$ ). In root of plants exposed to waterlogging conditions, the concentration of sucrose increased substantially, especially on $4^{\text {th }}$ day of experiment $(76.78 \%)$, followed by decrease, with a $24.75 \%$ lower sucrose concentration in waterlogged plants (16 ${ }^{\text {th }}$ day) compared to control (figure $2 b$ ).

\section{Waterlogging conditions effects on total soluble carbohydrate concentration}

Concentrations of total soluble carbohydrate in leaves were significantly higher in plants exposed to waterlogging (figure 3a). There was interaction between the factors $(P<0.001)$ and statistical differences among treatments $(P<0.001)$. However, showed no difference between evaluation periods ( $P<0.05)$ (figure 3$)$. In control and waterlogged plants, concentrations at 16 days were 1.21 and $2.36 \mathrm{mmol} / \mathrm{g} \mathrm{GLU}$ residue, respectively, showing an increase of $96.7 \%$ in plants exposed to waterlogging (figure $3 a$ ). In relation to total soluble carbohydrate concentrations at root, there was interaction between the factors $(P<0.001)$, statistical differences between treatments $(P<0.001)$ and periods of evaluation $(P<0.001$ ) (figure $3 \mathrm{~b})$. In control and waterlogged plants, at 16 days, the values were 0.87 and $1.80 \mathrm{mmol} / \mathrm{g} \mathrm{GLU}$ residue, showing an increase of $106.9 \%$ in plants exposed to waterlogging (figure $3 \mathrm{~b}$ ).

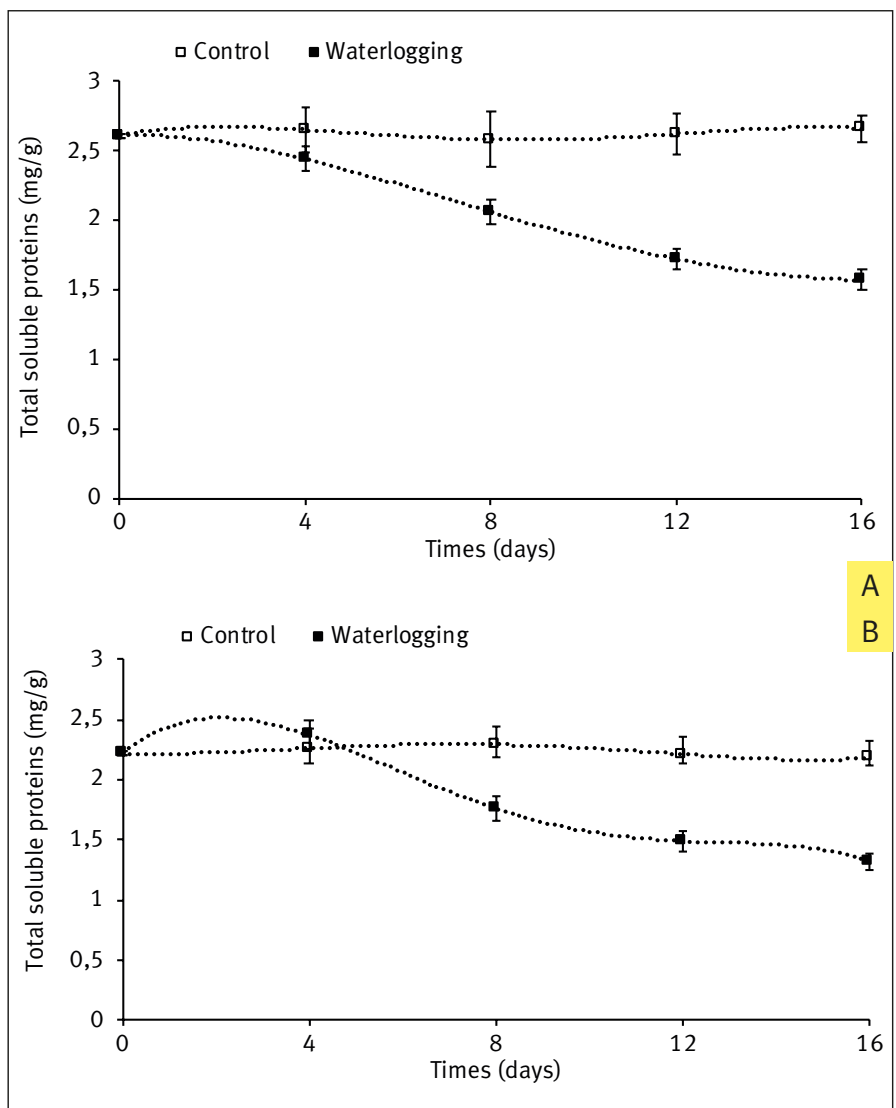

Figure 4.

Total soluble proteins concentration in the root $(A)$ and the leaf (B) in young Parkia gigantocarpa plants exposed to waterlogging conditions. Squares represent the mean values of five replicates, and error bars represent the mean standard errors. 


\section{Total soluble proteins concentration in leaves and roots}

Total soluble protein concentrations in leaves and roots of waterlogged plants were significantly reduced (figure $4 \mathrm{ab}$ ), showing a significant interaction between factors $(P<0.001)$, difference between treatments $(P<0.001)$ and evaluation times $(P<0.001)$ (figure 4$)$. At 16 days, total soluble protein concentrations in leaves were 2.66 and $1.57 \mathrm{mg} / \mathrm{g}$ DM protein in the control and waterlogged plants, respectively, showing a reduction of $40.98 \%$ in plants exposed to waterlogging (figure $4 a)$. Soluble protein concentrations in roots at 16 days were $2.18 \mathrm{mg} / \mathrm{g}$ protein DM (control plants) and $1.32 \mathrm{mg} / \mathrm{g}$ DM protein (waterlogged plants), showing a reduction of $39.45 \%$ in plants exposed to waterlogging (figure 4b).

\section{Discussion}

The reduction in starch concentration (figure 1) in P. gigantocarpa exposed to waterlogging conditions could be related to a decrease in stomatal conductance (gs), as shown by the significant positive correlation $(P<0.001)$ between the variables (table I). Thus, the reduction of $g s$ must have increased resistance to internal flow of $\mathrm{CO}_{2}$ in leaf tissues and influenced the lower acquisition of carbon through photosynthesis for construction of starch molecules. Another explanation is the activity of enzymes hydrolases $\alpha$ and $\beta$ amylase, acting on starch degradation in order to form sugars, especially sucrose, which promoted osmotic adjustment of tissues for the conservation of the internal flow of water plants by reducing water potential.

Moreover, the reduction of starch in plants exposed to waterlogging conditions would be an alternative to support fermentative metabolism, which requires higher sugar concentration (Miro and Ismail, 2013). Another possible explanation is that the synthesized carbohydrates were not stored as starch during the day, but directly transported to the phloem to supply the roots with additional carbohydrates (Peuke et al., 2015). Therefore, suggests that $P$. gigantocarpa in a short period of hypoxia increased the concentration of sucrose in root for the energy synthesis through fermentation, later, the reduction of sucrose would be justified by root necrosis with time of exposure of plant to stress.

The reduction in sucrose concentration in the leaves of young $P$. gigantocarpa plants is related to reduction in starch concentration, evidenced by the significant positive correlation $(\mathrm{P}<0.001)$ between the variables (table I) or due to increased rate of sucrose translocation from the leaves to the roots promoted by the activity of enzymes hydrolases $\alpha$ and $\beta$ amylase, which act in the degradation of starch. Alternatively, such reduction could be related to possible changes in the enzyme invertase (Arora et al., 2017).

The increase in sucrose concentration in the root (figure 2) possibly occurred to supplement or compensate the demand for carbohydrates needed to sustain the anaerobic metabolism of plants (Kreuzwieser et al., 2009; Arora et al., 2017) at least in the initial stages of waterlogging.

Table I.

Pearson correlation coefficient between starch in leaf $\left(\mathrm{St}_{\text {leaf }}\right)$, starch in root $\left(\mathrm{St}_{\text {root }}\right)$, Total soluble carbohydrates in leaf $\left(\mathrm{TSC}_{\text {leaf }}\right)$, Total soluble carbohydrates in root (TSC $\mathrm{rot}_{\text {rot }}$ ), sucrose concentration in leaf $\left(\mathrm{Sac}_{\text {lea }}\right)$, Sucrose concentration in root $\left(\mathrm{Sac}_{\text {roo }}\right)$, stomatal conductance $\mathrm{gs}$ ) an foliar xylem water potential $\left(\Psi_{x}\right)$ in young Parkia gigantocarpa plants exposed to waterlogging conditions.

\begin{tabular}{|c|c|c|c|c|c|}
\hline \multirow[t]{4}{*}{ Conditions } & & $\Psi_{\mathrm{x}}$ & gs & $\mathrm{St}_{\text {leaf }}$ & $\mathbf{S t}_{\text {root }}$ \\
\hline & $\mathrm{TSC}_{\text {leaf }}$ & $-0.1135^{\mathrm{ns}}$ & - & - & - \\
\hline & $\mathrm{TSC}_{\text {root }}$ & $0.0353^{\text {ns }}$ & - & - & - \\
\hline & $\mathrm{Sac}_{\text {leaf }}$ & - & - & $0.1144^{\mathrm{ns}}$ & $-0.2938^{\mathrm{ns}}$ \\
\hline \multirow[t]{7}{*}{ Control } & $\mathrm{Sac}_{\text {root }}$ & - & - & $0.0451^{\mathrm{ns}}$ & $-0.2538^{\mathrm{ns}}$ \\
\hline & $\mathrm{St}_{\text {leaf }}$ & - & $-0.0244^{\mathrm{ns}}$ & - & - \\
\hline & $\mathrm{St}_{\text {root }}$ & - & $0.0372^{\text {ns }}$ & - & - \\
\hline & $\mathrm{N}_{\text {leaf }}$ & - & $0.2238^{\text {ns }}$ & - & - \\
\hline & $\mathrm{TSC}_{\text {leaf }}$ & $-0.6893^{\star \star \star}$ & - & - & - \\
\hline & $\mathrm{TSC}_{\text {root }}$ & $-0.8964^{\star \star \star}$ & - & - & - \\
\hline & $\mathrm{Sac}_{\text {leaf }}$ & - & - & $0.9454^{\star \star \star}$ & $0.8335^{\star \star \star}$ \\
\hline \multirow[t]{4}{*}{ Waterlogging } & $\mathrm{Sac}_{\text {root }}$ & - & - & $0.2401^{\mathrm{ns}}$ & $0.0306^{\mathrm{ns}}$ \\
\hline & $S t_{\text {leaf }}$ & - & $0.8202^{\star \star \star}$ & - & - \\
\hline & $\mathrm{St}_{\text {root }}$ & - & $0.7090^{\star \star \star}$ & - & - \\
\hline & $\mathrm{N}_{\text {leaf }}$ & - & $0.4584^{*}$ & - & - \\
\hline
\end{tabular}


In general, waterlogging conditions increases TSC concentration in plants (Rosa et al., 2009). The accumulation of carbohydrates is considered to be important for protecting cellular structures such as biomembranes, which can be degraded by water stress in the hyaloplasm and by the increase in the concentration of ionic substances, inactivating several enzymes in the cytosol or for supply of the carbohydrate demand of shoots and root in anoxic conditions (Liu et al., 2011).

The increase of TSC concentration in leaves and roots (figure 3 ) in young $P$. gigantocarpa plants exposed to waterlogging conditions is related to reduction of water potential $\left(\Psi_{x}\right)$, as evidenced by the significant negative coefficient of correlation $(P<0.001)$ between the variables (table I). The accumulation of this compatible osmolyte, especially in the cytoplasm, reduces the osmotic potential of leaf tissue cells, and therefore its $\Psi_{x}$ (Jaleel et al., 2007) results in the $\Psi_{x}$ gradient between shoot-root-soil, allowing the absorption and soil water transport to the shoot, contributing to the maintenance of turgor cell. Thus, it can be inferred that during waterlogging conditions, $P$. gigantocarpa accumulated TSC that were used in osmotic adjustment of plant tissues to maintain water absorption.

The increase of TSC concentration in the roots (figure 3) of $P$. gigantocarpa exposed to waterlogging conditions shows that translocation of these substances was not affected by stress, suggesting a continuous transport of these substances to the roots (Islam and Macdonald, 2004). Although increased TSC concentration in roots of waterlogged plants has been reported as a form of stress tolerance (Araki et al., 2012), in this study the increase in TSC may have been a plant response as a result of lower demand of carbohydrates due to diminution of metabolism in roots and growth.

In hypoxic or anoxic conditions, protein synthesis is impaired, because it is a process for expenditure of energy demand (Nanjo et al., 2010) and, in these conditions, there is a decrease in ATP production.

Thus, the reduction of TSP (figure 4) in P. gigantocarpa exposed to waterlogging conditions suggests that plants under low availability of oxygen inhibit certain enzymes related to aerobic metabolism or active proteolytic enzymes that degrade protein accumulated in plants. Possibly, it is a plant defense strategy, since the amino acids resulting from the breakdown of proteins would be subject to interconversion for biosynthesis of specific amino acids (Reggiani et al., 2000), such as proline, which is directly related to osmotic adjustment of the leaf tissue. Alternatively, the amino acids would be used for synthesizing anaerobic polypeptides, such as alcohol dehydrogenase (ADH) and lactate dehydrogenase (LDH) as a way to compensate for the depletion of aerobic proteins (Zabalza et al., 2009).

Another explanation for the reduction of TSP in $P$. gigantocarpa exposed to waterlogging conditions is that ATP reduction in roots causes reduction of nitrogen metabolism, adversely affecting the activity of nitrate reductase and glutamine synthetase (Andrade Júnior et al., 2016). This can influence total nitrogen balance and amino acids, leading to a decrease of plant protein synthesis.

\section{Conclusion}

In plants exposed to waterlogging conditions, starch and soluble protein concentrations decreased in the leaves and roots, but total soluble carbohydrates increased in these organs.

Sucrose concentrations decreased in leaves and increased in the root of young Parkia gigantocarpa plants exposed to waterlogging conditions.

Thus, the data showed susceptibility of young $P$. gigantocarpa plants exposed to waterlogging conditions.

At 16 days of experiment, although in waterlogged plants the total soluble carbohydrates increased, the concentrations of starch, soluble protein and sucrose decreased, showing the sensitivity of young plants of $P$. gigantocarpa to waterlogging conditions.

\section{Acknowledgements}

The authors are grateful to the Research Group of Biodiversity Studies in Upper Plants of Federal Rural University of the Amazon. This research has the financial suport of National Council for Scientific and Technological Development (CNPq / Brasil).

\section{References}

Andrade Júnior W. V., Santos Filho B. G., Oliveira Neto C. F., Pereira A. C. C., Silva R. T. L., Viegas I. J. M., et al., 2016. Ecophysiological and biochemical behavior in young plants of Parkia gigantocarpa Ducke subjected to waterlogging conditions. African Journal of Agricultural Research, 11: 284-297.

Araki H., Hossain M. A., Takahashi T., 2012. Waterlogging and hypoxia have permanent effects on wheat root growth and respiration. Journal of Agronomy and Crop Science, 198: 264-275. https:// doi.org/10.1111/i.1439-037x.2012.00510.x

Arora K., Panda K. K., Mittal S., Mallikarjuna M. G., Rao A. R., Dash P. K., et al., 2017. RNAseq revealed the important gene pathways controlling adaptive mechanisms under waterlogged stress in maize. Scientific Reports, 7: 1-12. https://doi.org/10.1038/ s41598-017-10561-1

Bertolde F. Z., Almeida A.-A. F., Pirovani C. P., Gomes F. P., Ahnert D., Baligar V. C., et al., 2012. Physiological and biochemical responses of Theobroma cacao L. genotypes to flooding. Photosynthetica, 50: 447-457. https://doi.org/10.1007/s11099-012-0052-4

Bradford M. M., 1976. A rapid and sensitive method for the quantitation of microgram quantities of protein utilizing the principle of protein-dye binding. Analytical Biochemistry, 72: 248-254. https:// doi.org/10.1006/abio.1976.9999

Carvalho P. E. R., 2010. Espécies Arbóreas Brasileiras [Arboreal Brazilian species] Vol. 4. Embrapa Informação Tecnológica, Embrapa Florestas, 17 p. https://livimagens.sct.embrapa.br/amostras/00083860.pdf

Dubois M., Gilles K. A., Hamilton J. K., Rebers P. A., Smith F., 1956. Colorimetric method for determination of sugars and related substances. Analytical Biochemistry, 28: 350-356. https://doi. org/10.1021/ac60111a017 
IPCC, 2012. Summary for Policymakers. In: Field C. B., Barros V., Stocker T. F., Qin D., Dokken D. J., Ebi K. L., et al. (eds). Managing the Risks of Extreme Events and Disasters to Advance Climate Change Adaptation - A Special Report of Working Groups I and II of the Intergovernmental Panel on Climate Change. USA, Cambridge University Press, 3-19. https://www.ipcc.ch/site/assets/uploads/2018/03/ SREX Full Report-1.pdf

Islam M. A., Macdonald S. E., 2004. Ecophysiological adaptations of black spruce (Piceamariana) and tamarack (Larixlaricina) seedlings to flooding. Trees, 18: 35-42. https://doi.org/10.1007/ s00468-003-0276-9

Jaleel C. A., Manivannan P., Sankar B., Kishorekumar A., Panneerselvam R., 2007. Calcium chloride effects on salinity-induced oxidative stress, proline metabolism and indole alkaloid accumulation in Catharanthus roseus. Comptes Rendus Biologies, 330: 674-83. https://doi.org/10.1016/i.crvi.2007.07.002

Kreuzwieser J., Hauberg J., Howell K., Rennenberg A. C. H., Millar A. H., Whelan J., 2009. Differential Response of Gray Poplar Leaves and Roots Underpins Stress Adaptation during Hypoxia. Plant Physiology, 149: 461-473. https://doi.org/10.1104/pp.108.125989

Liu C. C., Liu Y., Liu K., Guo K., Fan D., Li G., Zheng Y., et al., 2011. Effect of trought on pigments, osmotic adjustment and antioxidante enzymes in six Woody plant species in karst habitats of southwestern China. Environmental and Experimental Botany, 71: 174-183. https://doi.org/10.1016/i.envexpbot.2010.11.012

Merchant A., Peuke A. D., Keitel C., Macfarlane C., Warren C. R., Adams M. A., 2010. Phloem sap and leaf $\delta^{13} C$, carbohydrates, and amino acid concentrations in Eucalyptus globulus change systematically according to flooding and water deficit treatment. Journal of Experimental Botany, 61: 1785-1793. https://doi.org/10.1093/ ixb/erq045

Miro B., Ismail A. M., 2013. Tolerance of anaerobic conditions caused by flooding during germination and early growth in rice (Oryza sativa L.). Frontiers in Plant Science, 4: 1-18. https://doi. org/10.3389/fpls.2013.00269

Mollard F. P. O., Striker G. G., Ploschuk E. L., Insausti P., 2010. Subtle topographical differences along a floodplain promote different plant strategies among Paspalum dilatatum subspecies and populations. Austral Ecology, 35: 189-196. https://doi. org/10.1111/j.1442-9993.2009.02026.x

Nanjo Y., Skultety L., Ashraf Y., Komatsu S., 2010. Comparative proteomic analysis of early-stage soybean seedlings responses to flooding by using gel and gel-free techniques. Journal of Proteome Research, 9: 3989-4002. https://doi.org/10.1021/pr100179f

Oliveira A. K. M., Ribeiro J. W. F., Pereira K. C. L., Rondon E. V., Becker T. J. A., Barbosa L. A., 2012. Superação de dormência em sementes de Parkia gigantocarpa (Fabaceae - Mimosidae). Ciência Florestal, 22: 533-540. https://doi.org/10.5902/198050986620

Patel P. K., Singh A. K., Tripathi N., Yadav D., Hemantaranjan A., 2014. Flooding: Abiotic Constraint Limiting Vegetable Productivity. Advances in Plants \& Agriculture Research, 1: 1-9. https://doi. org/10.15406/apar.2014.01.00016

Peuke A. D., Gessler A., Strumbore S., Windt C. W., Homan N., Gerkema E., et al., 2015. Phloem flow and sugar transport in Ricinus communis $L$. is inhibited under anoxic conditions of shoot or roots. Plant, Cell \& Environment, 38: 433-447.

Reggiani R., Nebuloni M., Mattana M., Brambilla I., 2000. Anaerobic accumulation of amino acids in rice roots: role of the glutamine synthetase/glutamate synthase cycle. Amino Acids, 18: 207-217. https://doi.org/10.1007/s007260050018

Reis L. P., Carvalho J. O. P., Reis P. C. M., Gomes J. M., Ruschel A. R., Silva M. G., 2014. Crescimento de mudas de Parkia gigantocarpa Ducke, em um sistema de enriquecimento em clareiras após a colheita de madeira. Ciência Florestal, 24: 431-436. https://doi. org/10.5902/1980509814583

Rosa M., Prado C., Podazza G., Interdonato R., González J. A., Hilal M., et al., 2009. Soluble sugars Metabolism, sensing and abiotic stress. Plant Signal Behavior, 4: 388-393.

Statistical Analisys System Institute - SAS, 2007. SAS® 9.1.3 (TS1M3) for Windows Microsoft. SAS Institute Inc., 212 p. https:// doi.org/10.4161/psb.4.5.8294

Steel R. G. D., Torrie J. H., Dickey D. A., 2006. Principles and procedures of statistics: A biometrical approach. 3rd edition. Moorpark, Ca, USA, Academic Internet Publishers, 666 p.

Van Handel E., 1968. Direct microdetermination of sucrose. Analytical Biochemistry, 22: 280-283. https://doi. org/10.1016/0003-2697(68)90317-5

Zabalza A., Dongen J. T. V., Froehlich A., Oliver S. N., Faix B., Gupta K. J., et al., 2009. Regulation of respiration and fermentation to control the plant internal oxygen concentration. Plant Physiology, 149: 1087-1098. https://doi.org/10.1104/pp.108.129288

\section{Viana de Andrade Júnior et al. - Author's contributions}

Contributor role

Conceptualization

Data Curation

Formal Analysis

Funding Acquisition

Methodology

Project Administration

Resources

Software

Supervision

Validation

Visualization

Writing - Original Draft Preparation

Writing - Review \& Editing

\section{Contributor names}

W. Viana de Andrade Júnior, B. Gomes dos Santos Filho, C. Ferreira de Oliveira Neto

W. Viana de Andrade Júnior, B. Gomes dos Santos Filho, C. Ferreira de Oliveira Neto

W. Viana de Andrade Júnior, B. Gomes dos Santos Filho, C. Ferreira de Oliveira Neto

This research had financial support from Conselho Nacional de Desenvolvimento Científico e Tecnológico (CNPq/Brazil) to W. Viana de Andrade Júnior

W. Viana de Andrade Júnior

W. Viana de Andrade Júnior, B. Gomes dos Santos Filho, C. Ferreira de Oliveira Neto

W. Viana de Andrade Júnior

C. Ferreira de Oliveira Neto, E. D. Cruz

R. Shigueru Okumura

B. Gomes dos Santos Filho, C. Ferreira de Oliveira Neto

W. Viana de Andrade Júnior.., B. Gomes dos Santos Filho, C. Ferreira de Oliveira Neto

W. Viana de Andrade Júnior

W. Viana de Andrade Júnior

V. Resende do Nascimento, J. Taynara da Silva Martins, L. Corrêa Machado, D. J. Palheta de Sousa, J. S. Silva Teixeira

Bois et Forêts des Tropiques - Revue scientifique du Cirad
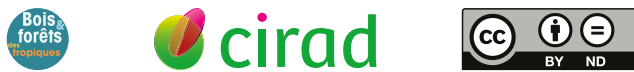

Cirad - Campus international de Baillarguet, 34398 Montpellier Cedex 5, France - Contact : bft@cirad.fr - ISSN : L-0006-579X 